\title{
Lime-Stabilized Black Cotton Soil and Brick Powder Mixture as Subbase Material
}

\author{
S. Srikanth Reddy (D) A. C. S. V. Prasad (D, and N. Vamsi Krishna \\ Department of Civil Engineering, SRKR Engineering College, Bhimavaram 534204, Andhra Pradesh, India \\ Correspondence should be addressed to S. Srikanth Reddy; srikanth.satti109@gmail.com
}

Received 21 August 2017; Revised 18 January 2018; Accepted 28 January 2018; Published 19 March 2018

Academic Editor: Venu G. M. Annamdas

Copyright (C) 2018 S. Srikanth Reddy et al. This is an open access article distributed under the Creative Commons Attribution License, which permits unrestricted use, distribution, and reproduction in any medium, provided the original work is properly cited.

\begin{abstract}
Various researchers, for the past few decades, had tried to stabilize black cotton soil using lime for improving its shrinkage and swelling characteristics. But these days, the cost of lime has increased resulting in increase in need for alternative and cost effective waste materials such as fly ash and rice husk ash. Brick powder, one among the alternative materials, is a fine powdered waste that contains higher proportions of silica and is found near brick kilns in rural areas. The objective of the study is to investigate the use of lime-stabilized black cotton soil and brick powder mixture as subbase material in flexible pavements. Black cotton soil procured from the local area, tested for suitability as subbase material, turned out to be unsuitable as it resulted in very less CBR value. Even lime stabilization of black cotton soil under study has not showed up the required CBR value specified for the subbase material of flexible pavement by MORTH. Hence the lime-stabilized black cotton soil is proportioned with brick powder to obtain optimum mixture that yields a better CBR value. The mixture of $20 \%$ brick powder and $80 \%$ lime-stabilized black cotton soil under study resulted in increase in the CBR value by about $135 \%$ in comparison with lime-stabilized black cotton soil. Thus it is promising to use the mixture of brick powder and lime-stabilized black cotton soil as subbase material in flexible pavements.
\end{abstract}

\section{Introduction}

Black cotton soils are boon to agriculture but are proved to be serious threat to construction founded on it. These soils have the property of high swelling due to imbibing of water in monsoon and shrinkage due to evaporation of water in summer seasons. This swelling and shrinkage nature is attributed to the presence of mineral montmorillonite. Because of this high swelling and shrinkage nature, the structures constructed on these soils experience cracks, making it unsuitable for foundation. Hence there is a need for improving black cotton soil to suite as foundation material.

Over the past few decades, stabilization is found to be the best technique for reducing the swelling and shrinkage nature of black cotton soil. Various researchers had tried stabilizing black cotton soil using lime, cement, fly ash, rich husk ash, etc. [1-5]. Of these, lime stabilization is one of the techniques which is in use for stabilizing black cotton soil from the past few decades. Use of lime reduces the high plasticity of black cotton and makes it workable. Also reaction between lime and soil makes the soil-lime mixture more strength resistant [1]. But in recent days, the cost of lime has increased. This resulted in increase of cost of lime stabilization of soil [2]. Also in the present study, an attempt is made in stabilizing the black cotton soil with lime which turned out to be unsuitable as subbase material. Hence the need for alternative and cost-effective materials has aroused.

Brick powder, a waste material available in abundance at brick kilns, is rich in silica and is available free of cost. Chemical analysis of brick powder showed rich composition of silica of about $55 \%$ along with minor compositions of iron oxide $(8 \%)$, aluminum oxide $(15 \%)$, calcium oxide $(7 \%)$, magnesium oxide (2\%), and sulfur trioxide (1\%) [6]. Brick powder is being successfully used in mortar and concrete making from the past few decades. It is reported that utilization of $25 \%$ brick powder in concrete making resulted in adequate strength and thermal resistance and also addressed cost effectiveness and environmental issues [6]. Partial replacement of cement with brick powder in mortar has showed that with use of brick powder the recycled-aggregate 
mortar seemed to be superior in terms of mortar-brick bond strength mainly because of its rheological properties [7]. Use of brick powder as a partial substitute for sand in concrete showed a reduction in unit weight of concrete and had improved the strength of concrete adequately [8]. Also use of brick powder in cement mortar reduces the deterioration effect of alkali-silica reactions [9].

Recent studies led to beneficial use of brick powder in pavements. Brick powder when used as an alternative filler in asphalt mixture resulted in improved mechanical properties of the wearing course of flexible pavements $[10,11]$.

Studies on use of brick powder as stabilizer for black cotton soil showed that when about $50 \%$ brick powder is mixed with black cotton soil there has been significant increase in strength aspects of the soil [12]. But use of brick powder alone for stabilization of black cotton soil requires it in huge amounts. Mixing other materials along with brick powder for stabilizing black cotton soil reduces the problem of procuring the material. Brick aggregate when used in fly ash-lime-stabilized black cotton soil improved the strength characteristics of black cotton soil for use as base course in pavements [13]. Brick dust along with bagasse ash used for stabilizing black cotton soil improved the unconfined compressive strength of the soil significantly [14].

Not much literature is available on combined use of lime-stabilized soil and brick powder as a subbase in flexible pavements. Hence in the present study an attempt is made to proportion lime-stabilized black cotton soil and brick powder, with an objective of obtaining a cost-effective mixture that is suitable for use as subbase material for village roads where brick powder is abundantly available.

\section{Characterization of Black Cotton Soil}

Black cotton soil used in the study is procured from Bhimavaram area of Andhra Pradesh, India. Extensive laboratory work is carried out to characterize the black cotton soil. The plasticity index is calculated by determining Atterberg's limits. Compaction characteristics are determined by conducting IS light compaction test and strength characteristics by conducting California bearing ratio (CBR) test. The results obtained are presented in Table 1 .

\section{Engineering Properties of Brick Powder}

The engineering properties of the brick powder, procured from local brick kiln in Bhimavaram, are determined by carrying out extensive laboratory tests, namely, grain size analysis, Atterberg's limit tests, IS light compaction test, and soaked CBR test, and the results obtained are tabulated in Table 2 .

\section{Lime Stabilization of Black Cotton Soil}

Black cotton soil is mixed with lime in varying proportions of $2 \%, 4 \%$, and $6 \%$. The lime-mixed soil is then cured for a duration of 3 days. The mixture is then oven-dried for 24 hours. The results of various tests carried out on black cotton soil mixed with varying percentages of lime are tabulated in Table 3.
TABLE 1: Engineering properties of black cotton soil.

\begin{tabular}{lc}
\hline Engineering property & Value \\
\hline Specific gravity & 2.67 \\
Grain size analysis & \\
$\quad$ (a) Gravel size (\%) & 0 \\
(b) Sand size (\%) & 4 \\
(c) Fines (\%) & 96 \\
Plasticity characteristics & \\
$\quad$ (a) Liquid limit (\%) & 86 \\
(b) Plastic limit (\%) & 40.6 \\
(c) Plasticity index (\%) & 45.4 \\
IS classification & $\mathrm{CH}$ \\
Differential free swell (DFS) index (\%) & 100 \\
IS light compaction & \\
Maximum dry density (g/cc) & 1.36 \\
Optimum moisture content (\%) & 33 \\
Soaked CBR (\%) & 1.17 \\
\hline
\end{tabular}

TABLE 2: Engineering properties of brick powder.

\begin{tabular}{lc}
\hline Engineering property & Value \\
\hline Grain size analysis & \\
(a) Gravel size (\%) & 0 \\
(b) Sand size (\%) & 86 \\
(c) Fines (\%) & 14 \\
Plasticity characteristics & $\mathrm{NP}$ \\
(a) Liquid limit (\%) & $\mathrm{NP}$ \\
(b) Plastic limit (\%) & $\mathrm{SM}$ \\
IS classification & \\
IS light compaction & 1.30 \\
Maximum dry density (g/cc) & 33 \\
Optimum moisture content (\%) & 21.17 \\
Soaked CBR (\%) &
\end{tabular}

TABle 3: Properties of black cotton soil stabilized with varying contents of lime.

\begin{tabular}{lccc}
\hline Engineering property & $\begin{array}{c}2 \% \\
\text { lime }\end{array}$ & $\begin{array}{c}4 \% \\
\text { lime }\end{array}$ & $\begin{array}{c}6 \% \\
\text { lime }\end{array}$ \\
\hline $\begin{array}{l}\text { Plasticity characteristics } \\
\quad \text { (a) Liquid limit (\%) }\end{array}$ & 64.4 & $\mathrm{NP}$ & $\mathrm{NP}$ \\
$\quad$ (b) Plastic limit (\%) & 34.0 & $\mathrm{NP}$ & $\mathrm{NP}$ \\
$\quad$ (c) Plasticity index (\%) & 30.4 & $\mathrm{NP}$ & $\mathrm{NP}$ \\
$\begin{array}{l}\text { Differential free swell (DFS) index } \\
\text { (\%) }\end{array}$ & 90 & 60 & 40 \\
IS light compaction & & & \\
Maximum dry density (g/cc) & 1.37 & 1.51 & 1.34 \\
Optimum moisture content (\%) & 28 & 25 & 32 \\
Soaked CBR (\%) & 7.59 & 8.52 & 0.62 \\
\hline
\end{tabular}

From Tables 1 and 3, it can be observed that the plasticity index of the soil under study had decreased from $45.4 \%$ for $0 \%$ lime to $30.4 \%$ for $2 \%$ lime and thereafter the soil had become nonplastic (NP) with increase in the lime content.

The differential free swell index of the black cotton had decreased from $100 \%$ to $40 \%$ with increase in the lime content from $0 \%$ to $6 \%$. Figure 1 shows the variation of differential free swell index with increasing content of lime. 


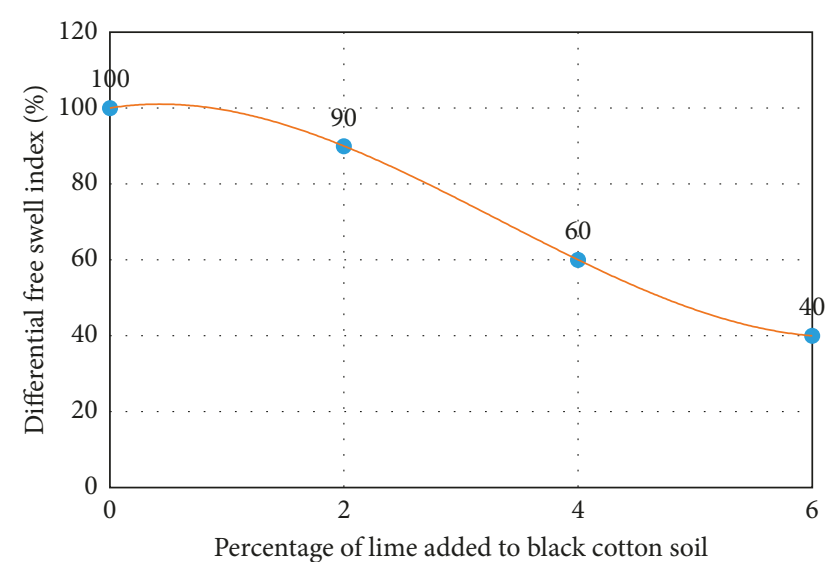

FIGURE 1: Variation of differential free swell index with varying percentages of lime.

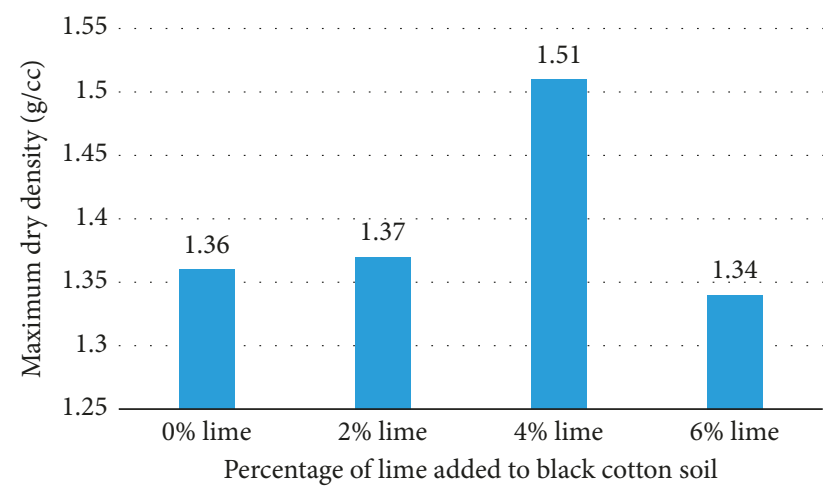

FIGURE 2: Variation of maximum dry density with varying percentage of lime.

Compaction characteristics of lime-stabilized soil are determined by conducting the IS light compaction test. Figure 2 shows the variation of maximum dry density with varying percentages of lime added to black cotton soil. It can be observed that the maximum dry density of the black cotton soil increased from $0 \%$ lime content to $4 \%$ lime and thereafter it decreased.

Figure 3 shows the decrease of the optimum moisture content from $33 \%$ to $25 \%$ for a lime content of $0 \%$ to $4 \%$ and thereafter the optimum moisture content had increased to $32 \%$ for increase of the lime content to $6 \%$.

The strength characteristics of the lime-stabilized black cotton soil are determined by conducting soaked CBR test on the samples compacted to maximum dry density (MDD) obtained from the IS light compaction test and soaked for a duration of 3 days. The variation of soaked CBR for different lime contents is presented in Figure 4. It can be seen that the soaked CBR value had increased from $1.17 \%$ to $8.52 \%$ for an increase in the lime content from $0 \%$ to $4 \%$ and thereafter the soaked CBR value had decreased to $0.62 \%$ for a lime content of $6 \%$.

Based on the soaked CBR tests on black cotton soil, $4 \%$ lime content is taken as optimum lime content for

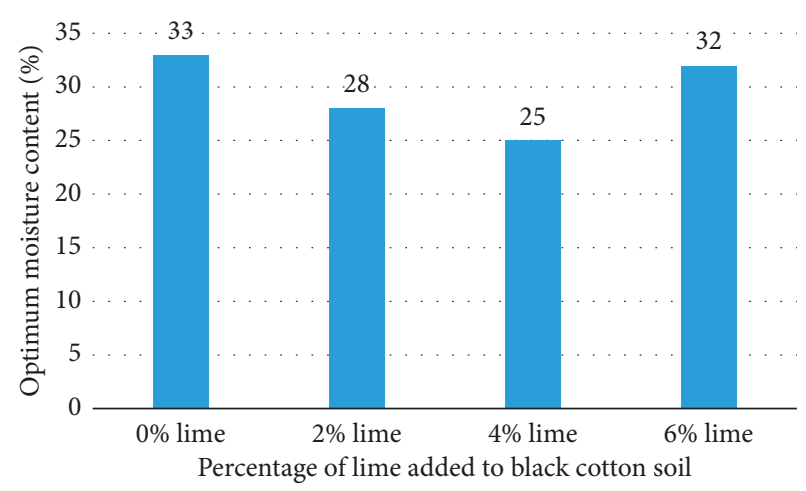

FIGURE 3: Variation of optimum moisture content with varying percentages of lime.

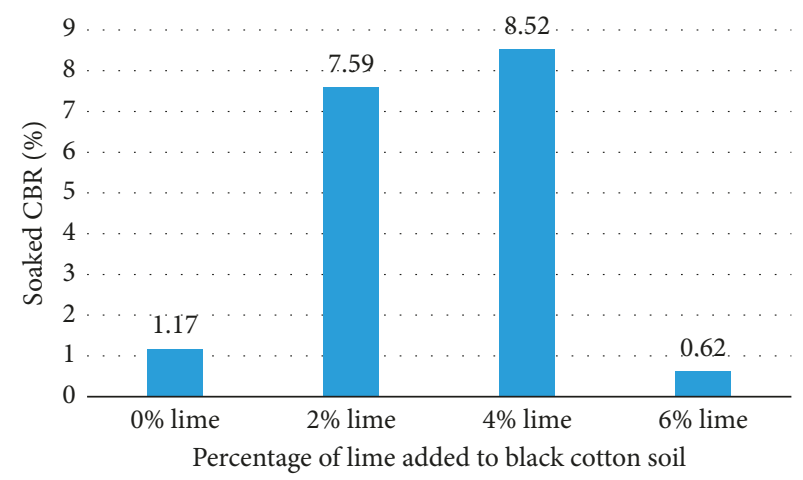

FIGURE 4: Variation of soaked CBR with varying contents of lime.

stabilization as the soaked CBR value for $4 \%$ lime content is higher compared to that of other contents of lime.

\section{Proportioning of Brick Powder and Lime- Stabilized Black Cotton Soil Mixture}

Addition of $4 \%$ lime to black cotton soil for stabilization did not yield the required value of CBR of $20 \%$ for subbase (Clause 401, Morth). Hence the lime-stabilized black cotton soil is mixed with brick powder, as it is rich in silica, in various proportions to obtain the optimum mixture suitable for use as subbase material. Also use of brick powder reduces the cost, as it is freely available at brick kilns. Lime-stabilized black cotton soil (LS) and brick powder (BP) are mixed in various proportions viz. $80 \% \mathrm{LS}+20 \% \mathrm{BP}, 60 \% \mathrm{LS}+40 \% \mathrm{BP}$, $40 \% \mathrm{LS}+60 \% \mathrm{BP}$, and $20 \% \mathrm{LS}+80 \%$ BP. Maximum dry density and optimum moisture content of each proportion are determine by carrying out the IS light compaction test. $\mathrm{CBR}$ of the mixture is determined by carrying out the soaked CBR test. The results so obtained are presented in Table 4.

Table 4 shows the variation of maximum dry density for various mix proportions of brick powder and lime-stabilized black cotton soil. Maximum dry density decreased from $2.02 \mathrm{~g} / \mathrm{cc}$ for $80 \% \mathrm{LS}+20 \% \mathrm{BP}$ to $1.73 \mathrm{~g} / \mathrm{cc}$ for $20 \% \mathrm{LS}+80 \%$ BP. The variation of optimum moisture content for various mix proportions of brick powder and lime-stabilized black 
TABLE 4: Engineering properties of brick powder and lime-stabilized black cotton soil mixture.

\begin{tabular}{lcccc}
\hline Engineering property & $80 \%$ LS +20\% BP & $60 \%$ LS + 40\% BP & $40 \%$ LS + 60\% BP & $20 \%$ LS + 80\% BP \\
\hline IS light compaction & & & & \\
(a) Maximum dry density (g/cc) & 2.02 & 1.83 & 1.80 & 1.73 \\
(b) Optimum moisture content (\%) & $17 \%$ & $21 \%$ & $25 \%$ & $29 \%$ \\
CBR (\%) & 20.07 & 7.81 & 4.67 & 11.82 \\
\hline
\end{tabular}

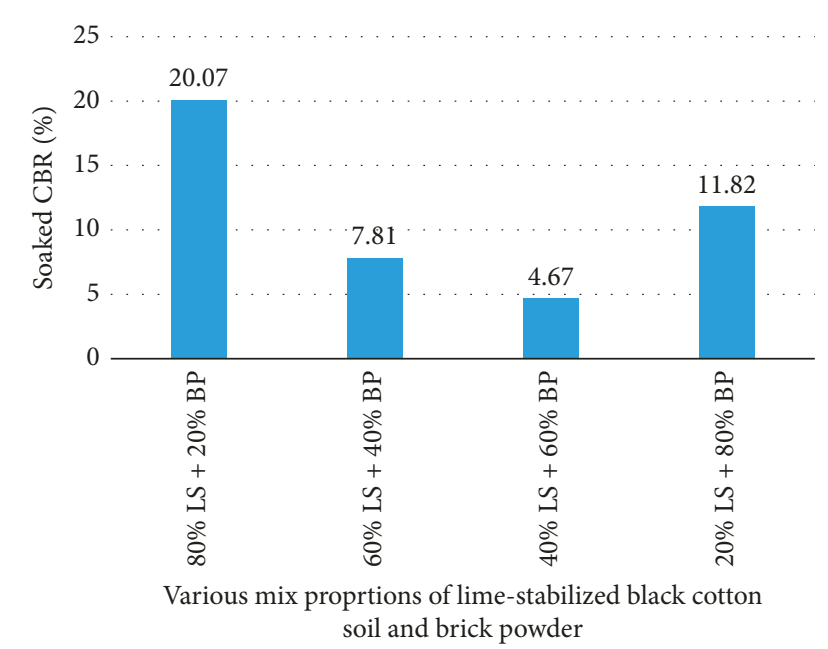

FIgURE 5: Variation of soaked CBR for different mix proportions of lime-stabilized black cotton soil and brick powder.

cotton soil is also presented in Table 4. Optimum moisture content increased from $17 \%$ for $80 \%$ LS $+20 \%$ BP to $29 \%$ for $20 \% \mathrm{LS}+80 \% \mathrm{BP}$. The decrease in maximum dry density and increase in the optimum moisture content, with increase of brick powder content, is attributed to the low maximum dry density and high optimum moisture content of brick powder shown in Table 2.

Variation of soaked CBR for different mix proportions of brick powder and lime-stabilized black cotton soil is presented in Figure 5. The soaked CBR value decreased from $20.07 \%$ for $80 \%$ LS $+20 \%$ BP to $4.67 \%$ for $40 \%$ LS $+60 \%$ BP and then increased to $11.82 \%$ for $20 \% \mathrm{LS}+80 \% \mathrm{BP}$.

\section{Conclusions}

From the study carried out on brick powder and limestabilized black cotton soil mixture, the following conclusions can be drawn:

(1) Lime stabilization of black cotton soil under study improved the strength characteristics of the soil, but not to the extent of suitability as subbase material.

(2) Mixing $20 \%$ brick powder and $80 \%$ lime-stabilized black cotton soil improved the maximum dry density and decreased the optimum moisture content in comparison to $4 \%$ lime stabilized soil.

(3) $80 \%$ lime-stabilized black cotton soil and $20 \%$ brick powder mixture resulted in increase in the soaked CBR value by about $135 \%$, when compared to $4 \%$ lime-stabilized soil, making it satisfactory for use as subbase material.

(4) Use of brick powder reduces the content of lime which in turn reduces the cost of project as brick powder is freely available. Also, use of brick powder reduces the problem of waste disposal.

Hence brick powder and lime-stabilized black cotton soil mixture can be effectively used as subbase material in flexible pavements of rural areas where brick powder is available in good amounts and also in areas with less availability of good quality materials.

\section{Conflicts of Interest}

The authors declare that they have no conflicts of interest.

\section{References}

[1] B. Mishra, "A study on engineering behavior of black cotton soil and its stabilization by use of lime," International Journal of Science and Research, vol. 4, no. 11, pp. 290-294, 2015.

[2] S. Bhuvaneshwari, G. Robinson, and S. Gandhi, "Stabilization of expansive soils using flyash," in Proceedings of the Fly Ash India 2005, vol. 8, pp. 5.1-5.6, New Delhi, India, December 2005.

[3] J. Oja and P. Gundaliya, "Study of black cotton soil characteristics with cement waste dust and lime," in Proceedings of the Nirma University International Conference on Engineering (NUiCONE 2012), pp. 110-118, Gujarat, India, December 2013.

[4] R. Rathan Raj, S. Banupriya, and R. Dharani, "Stabilization of soil using rice husk ash," International Journal of Computational Engineering Research, vol. 6, no. 2, pp. 43-50, 2016.

[5] M. K. Mohanty, Stabilization of Expansive Soil Using Fly Ash, Department of Civil Engineering, National Institute of Technology, Rourkela, Odisha, India, 2015.

[6] A. Ali Aliabdo, M. Abd-Elmoaty, and H. Hani Hassan, "Utilization of crushed clay brick in cellular concrete production," Alexandria Engineering Journal, vol. 53, no. 1, pp. 119-130, 2014.

[7] G. Moriconi, V. Corinaldesi, and R. Antonucci, "Environmentally friendly mortars: a way to improve bond between mortar and brick," Materials and Structures, vol. 36, no. 10, pp. 702-708, 2003.

[8] D. Tavakoli, A. Heidari, and S. H. Pilehrood, "Properties of concrete made with waste clay brick as sand incorporating $\mathrm{SiO}_{2}$," Indian Journal of Science and Technology, vol. 7, no. 12, pp. 1899-1905, 2014.

[9] L. Turanli, F. Bektas, and P. Monterio, "Use of ground clay brick as a pozzolanic material to reduce the alkali silica reaction," Cement and Concrete Research, vol. 33, no. 10, pp. 1539-1542, 2003. 
[10] M.-Z. Chen, J.-T. Lin, S.-P. Wu, and C.-H. Liu, "Utilization of recycled brick powder as alternative filler in asphalt mixture," Construction and Building Materials, vol. 25, no. 4, pp. 1532-1536, 2011.

[11] S. Wu, J. Zhu, J. Zhong, and D. Wang, "Experimental investigation on related properties of asphalt mastic containing recycled red brick powder," Construction and Building Materials, vol. 25, no. 6, pp. 2883-2887, 2011.

[12] S. N. Bhavsar, H. B. Joshi, P. K. Shrof, and A. J. Patel, "Effect of burnt brick dust on engineering properties of expansive soil," International Journal of Research in Engineering and Technology, vol. 3, no. 4, pp. 433-441, 2014.

[13] B. R. Malhotra and K. A. John, "Use of lime-fly ash-soilaggregate mix as a base course," Indian Highways, vol. 14, no. 5, pp. 23-32, 1986.

[14] K. Sudharani, S. K. Abhishek, N. Adarsh, and Manjunath, "Stabilization of black cotton soil using brick dust and bagasse ash," International Journal for Scientific Research and Development, vol. 5, no. 5, pp. 140-144, 2017. 


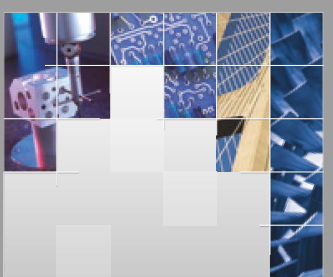

\section{Enfincering}
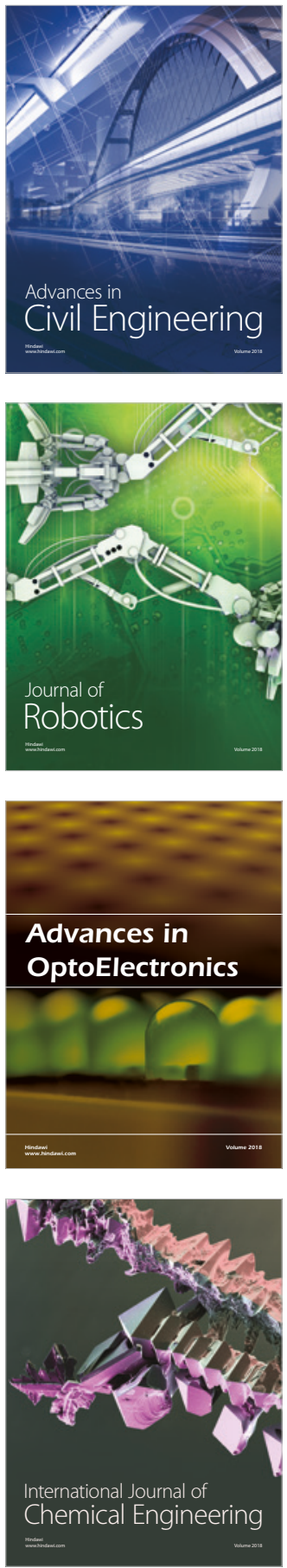

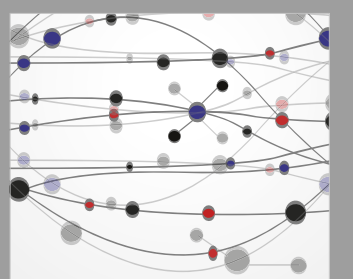

\section{Rotating \\ Machinery}

The Scientific World Journal

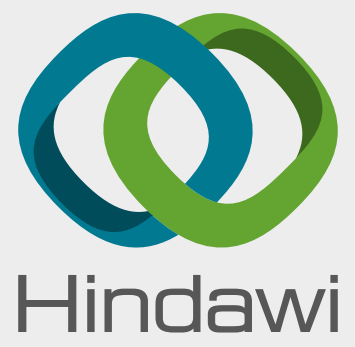

Submit your manuscripts at

www.hindawi.com
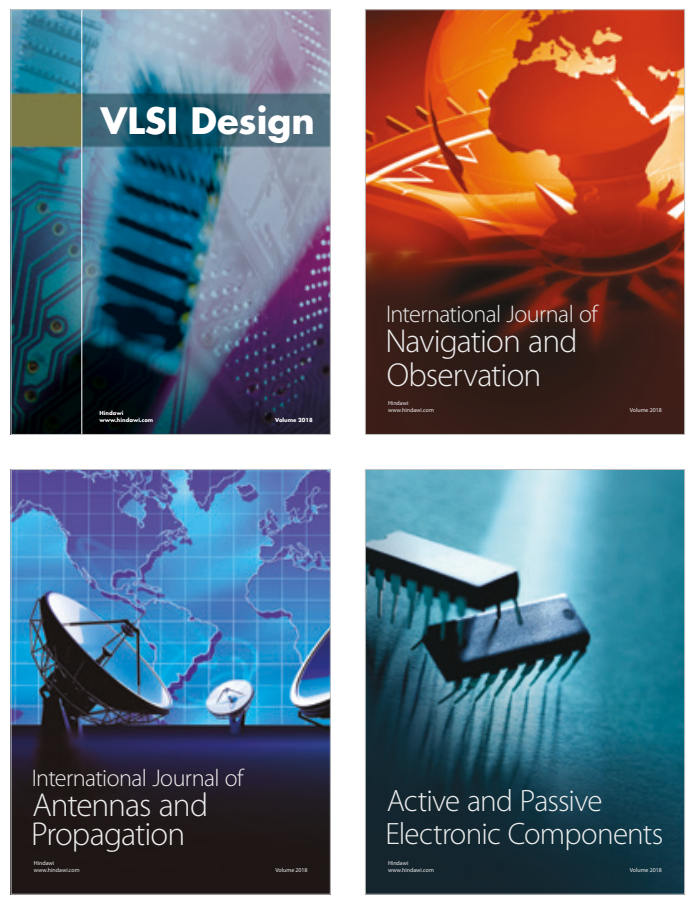
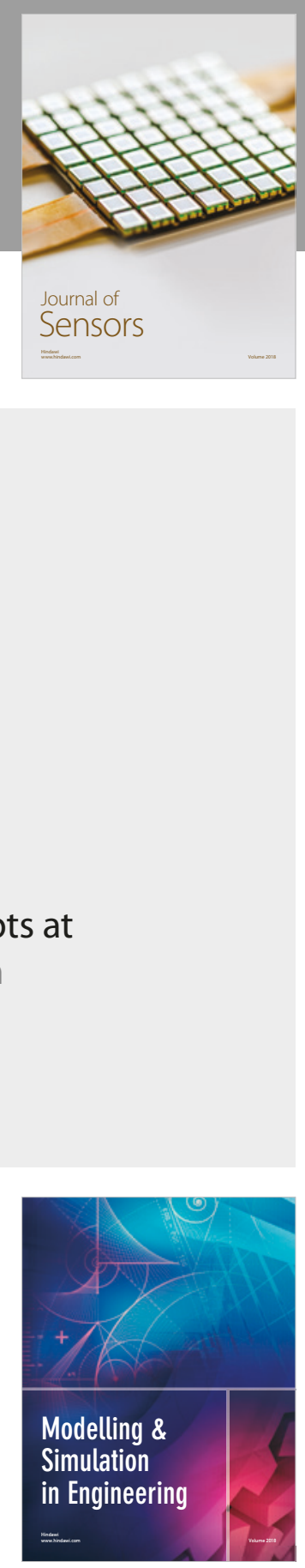

\section{Advances \\ Multimedia}
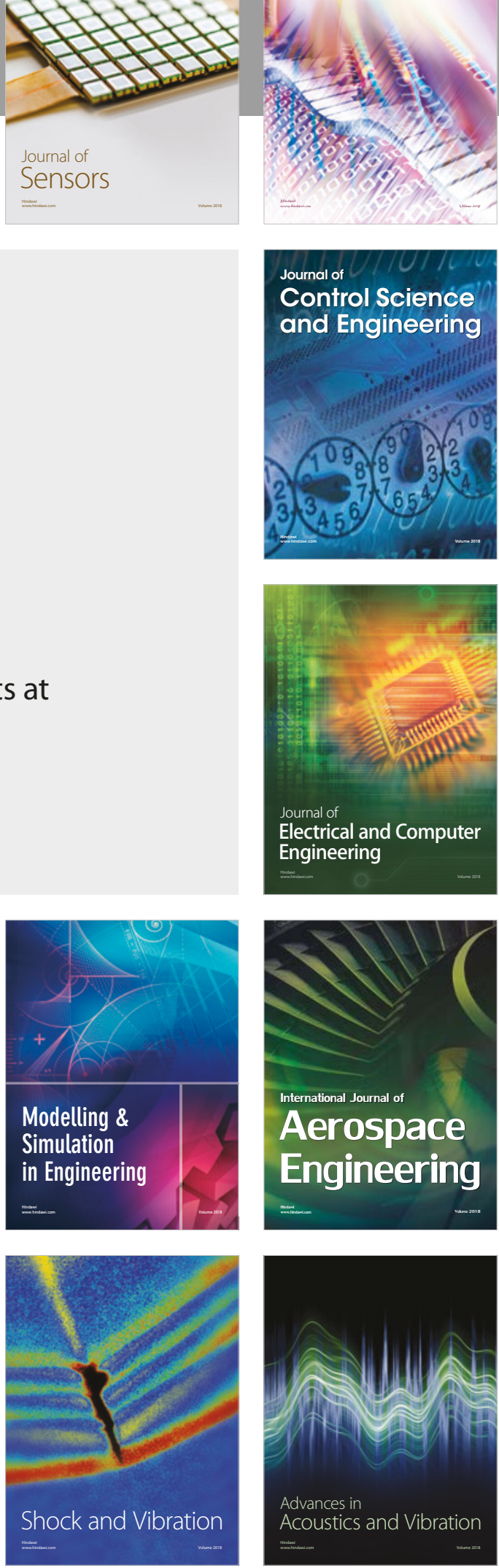